\title{
Effect of Flapless Implant Surgery on Soft Tissue Profile: A Randomized Controlled Clinical Trial
}

\author{
Tae-Ju Oh, * Jeffrey L. Shotwell, ${ }^{\dagger}$ Edward J. Billy, ${ }^{\dagger}$ and Hom-Lay Wang*
}

Background: Flapless implant surgery has been suggested as one possible treatment option for enhancement of implant esthetics.

Methods: Twenty-four patients with a missing tooth in the premaxillary region were randomly assigned to one of two groups (12 each): immediate loading (IL) or delayed loading (DL) (loading after 4 months). An endosseous implant was placed in each patient via a flapless surgery. Clinical measurements including the papillary index (PPI) (0, no papilla; 1 , less than half; 2 , more than half but not complete fill; 3, complete fill; and 4, overfill), marginal levels of the soft tissue (ML), probing depths (PDs), modified bleeding index $(\mathrm{mBI})$, modified plaque index $(\mathrm{mPI})$, and the width of the keratinized mucosa (WKM) were performed at baseline (at the time of loading) and at 2, 4, and 6 months.

Results: The soft tissue profile remained stable up to 6 months, without significant differences between the two groups (mean PPI and ML at 6 months, 2.16 and $0.30 \mathrm{~mm}$, respectively). Mean PPI in the IL group significantly increased from 1.50 at baseline to 2.09 at 2 months, and the significance remained up to 6 months (2.30 at 6 months) $(P<0.05)$, whereas in the DL group, no significant changes were found from baseline to 6 months in mean PPI (2.06 at both time points). Mean PPI increased over time when two treatment groups were combined; however, no statistical significance was found. In ML, the difference at baseline between the two groups $(-0.28 \mathrm{~mm}$ for DL versus $0.17 \mathrm{~mm}$ for IL; $P<0.05)$ was no longer significant at 2 months ( 0 versus $0.08 \mathrm{~mm}$ for DL and IL, respectively) and thereafter $(P>0.05)$. No significant differences were detected between groups at each time and over time in the other clinical parameters, PD, mBI, mPI, and WKM $(P>0.05)$.

Conclusions: The results of this study indicate that creeping attachment (i.e., soft tissue recovery) might occur within 2 months after IL. The study suggests that flapless implant surgery provides esthetic soft tissue results in single-tooth implants either immediately or delayed loaded. Other long-term randomized controlled clinical trials with a large sample size and comparison group (i.e., implant surgery with flap) are recommended to verify the conclusions drawn in this preliminary study. J Periodontol 2006;77: 874-882.

\section{KEY WORDS}

Dental implant; immediate loading; preservation; single-tooth implant; surgery.

\footnotetext{
* Department of Periodontics and Oral Medicine, School of Dentistry, University of Michigan, Ann Arbor, MI.

$\dagger$ Department of Biologic and Materials Science, School of Dentistry, University of Michigan.
}

$\square$ ental implant therapy has been demonstrated to be a highly successful and predictable treatment modality for replacement of missing teeth. ${ }^{1-9}$ In the decades when osseointegration was the main concern, a healing period of 3 to 6 months (submerged implants) with a load-free environment to facilitate undisturbed healing was generally recommended and adopted. ${ }^{10}$ However, this concept has been challenged by successful results shown in several animal and longitudinal studies using a one-stage surgical protocol (non-submerged implants) and/or immediate loading (IL) of implants. ${ }^{11-26}$ The favorable outcomes from the above studies enabled clinicians to broaden the arena of implant dentistry, enhancing esthetic and functional outcomes in addition to osseointegration. Moreover, the acceleration of treatment time and less surgical intervention via IL protocol and one-stage surgical approach can significantly enhance patient comfort, satisfaction, and acceptance. For example, esthetic, functional, and psychological problems from anodontia, especially in the premaxillary region, can be remarkably reduced by omitting the waiting period.

The concept of IL has been actively investigated, mainly in situations

doi: $10.1902 / j o p .2006 .050169$ 
of the edentulous mandible. ${ }^{22,24,27-32}$ In a human histologic study, immediately loaded implants in the edentulous mandible demonstrated high bone-to-implant contacts, ranging from $78 \%$ to $85 \% .{ }^{29}$ In addition, the same research group reported a $97.4 \%$ implant success rate on immediately loaded implants using hybrid prostheses supported by five to six implants in the edentulous mandible. ${ }^{22}$ Chiapasco et al. ${ }^{24} \mathrm{com}$ pared the effect of IL and delayed loading (DL) of implants with implant-retained mandibular overdentures. The results of the study showed that there were no significant differences between the two groups in modified plaque index (mPI), modified bleeding index $(\mathrm{mBI})$, values of an electronic mobility testing device, ${ }^{\dagger}$ peri-implant bone resorption, and probing depth (PD) at 24 months after prosthetic load. The cumulative success rate of implants was $97.5 \%$ in both groups, suggesting that IL is not detrimental for osseointegration.

With the rapid advancement of dental implant therapeutics, the current trend is more geared toward enhancing esthetics and patient comfort and satisfaction. Papilla preservation and predictable soft tissue margins around dental implants are major esthetic concerns, particularly for patients who have a high smile line. ${ }^{33,34}$ There has been a report of postsurgical tissue loss from flap reflection, ${ }^{35}$ implying that flap surgery for implant placement may negatively influence implant esthetic outcomes, especially in the anterior maxilla. Van der Zee et al. ${ }^{35}$ investigated the effect of flap reflection on soft tissue profile of adjacent dentition using guided bone regeneration (GBR) cases. The study found that there was a small but statistically significant amount of proximal gingival recession $(0.75 \mathrm{~mm})$ and bone resorption $(0.34 \mathrm{~mm})$ 12 months after GBR surgery. It was speculated that the tissue loss might have resulted from flap reflection.

Flapless implant surgery has been suggested as a treatment modality for the preservation of the soft tissue and for increasing patient comfort and satisfaction. ${ }^{36-41}$ Although there have been several reports with regard to clinical outcomes of IL and/or flapless implant surgery on single-tooth implants, ${ }^{16,39-44}$ limited controlled data have been available for the evaluation of soft tissue profiles of flapless implant surgery on single-tooth implants. Therefore, the purpose of this study was to examine the soft tissue profile changes of single-tooth implants in the premaxillary region after flapless implant surgery, comparing IL to DL.

\section{MATERIALS AND METHODS}

For this randomized parallel-arm controlled clinical trial, 24 patients requiring single-tooth implant replacement in the premaxillary region were recruited at the University of Michigan School of Dentistry.
The subjects were randomly assigned to one of two groups: IL (12 patients) or DL (12 patients). The IL group had their implants loaded with a temporary crown in occlusal contact immediately after fixture placement, and the temporary crown was replaced with a permanent crown 10 to 14 days later. On the other hand, the DL group had their implants loaded 4 months after implantation, as recommended by the manufacturer. $\S$ Informed consent was obtained from all subjects, and the use of human subjects in this project was approved by the University of Michigan institutional review board. There were no subject enrollment restrictions based on race or ethnic origin. The study period (from patient enrollment to data collection) was between June 2003 and October 2004.

\section{Surgical and Prosthodontic Procedures}

Before surgery, alginate impressions and cast fabrication were carried out for all patients. A series of surgical stents, size customized to implant drills, were made in each case from the cast using the technique described by Shotwell et al. ${ }^{45}$ Ideal implant angulation was determined on the cast using a dental surveyor. The proposed implant site was marked and drilled in the cast using a bench-top drill press and drill bits matching the ascending size of the surgical drills. By sequentially placing drill blanks matched to the diameter of the holes prepared in the cast, a series of customized surgical stents was fabricated for each patient using a light-polymerized composite material. Under local anesthesia with $2 \%$ xylocaine $(1: 100,000$ epinephrine), the soft tissue of the proposed implant site was ink-marked, guided by the surgical stent, and punched with a $4-\mathrm{mm}$ tissue punch "Figs. 1A and 2A). After a tissue punch was made, the soft tissue thickness was measured using a University of North Carolina (UNC) probe." Implant osteotomy and placement were performed using the sizecustomized implant drill guides, according to the manufacturer's surgical protocol.** A periapical radiograph was taken during the osteotomy to ensure appropriate angulation and length of the proposed implant site (Figs. 1B and 2B). All patients received a root-form endosseous implant, 3.7 or $4.7 \mathrm{~mm}$ in diameter and 10 or $13 \mathrm{~mm}$ in length, via flapless surgery. All surgical procedures were preformed by two trained periodontists (T-JO and H-LW). A fixturelevel transfer index was taken immediately after implant placement using a light-polymerized composite material ${ }^{\dagger \dagger}$ by connecting the implant transfer coping to a surgical stent modified for this purpose (Figs. 1C

\footnotetext{
‡ Periotest, Siemens, Bensheim, Germany

$\S$ Zimmer Dental, Carlsbad, CA.

Triad, Dentsply, York, PA.

II Zimmer Dental.

\# Hu-Friedy, Chicago, IL.

** Zimmer Dental.

$\dagger \dagger$ Triad, Dentsply.
} 

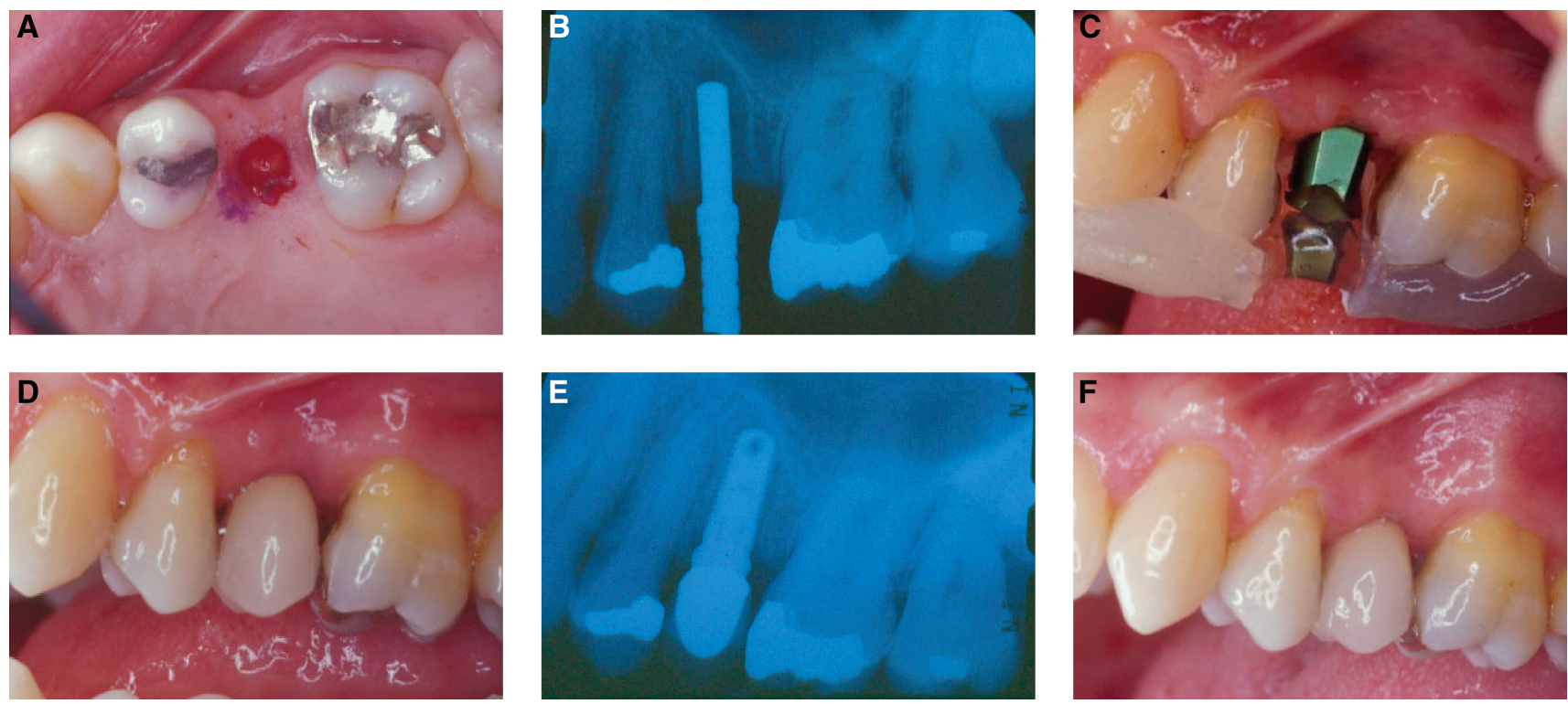

Figure $I$.

Immediate loading group. A) A tissue punch was made on the area of tooth \# 3 for flapless implant surgery. B) A periapical radiograph was taken to verify the angulation and length of implant osteotomy. C) After implant insertion, a fixture-level transfer stent was obtained using a light-polymerized composite resin material connected to the surgical stent. D) The permanent crown was placed, replacing a temporary crown, 10 days after implant placement surgery. E) Another periapical radiograph was taken to confirm appropriate positioning of implant and implant restoration. F) The photograph taken at 6-month follow-up demonstrates recovery of interdental papillae both mesially and distally.

and 2C). The index was secured with an implant analog in the cast and sent to a dental laboratory for the fabrication of a permanent crown. For the patient in the IL group, a temporary crown was fabricated with acrylic resin using a hollowed-out denture tooth and prefabricated temporary abutment at chair side. This method was used to minimize exposure of the surgical site to polymethyl methacrylate (PMMA) during the fabrication of the temporary crown. Once the temporary crown was adjusted and verified, the prefabricated temporary abutment was hand-torqued to the implant and the temporary crown was cemented to the abutment with a temporary cement. ${ }^{\ddagger}$ The patient was followed up at 10 to 14 days after implant surgery. At this time, the temporary crown was removed, the final abutment was torqued to $30 \mathrm{Ncm}$, and a permanent crown (ceramic metal crown) was delivered (Figs. 1D and 1E). For the DL group, all of the same procedures were carried out as IL, except for the temporization of the implant site. Instead of a temporary crown, a healing abutment was placed over the implant after implant placement, and permanent crowns were delivered 4 months after implantation in DL (Figs. 2D and 2E). All prosthodontic procedures were performed by two experienced prostodontists (JLS and EJB).

\section{Clinical Evaluation}

The parameters evaluated were implant success rates, papillary index (PPI), ${ }^{46}$ marginal levels of the soft tissue (ML), PDs, $\mathrm{mBI}$, and $\mathrm{mPI},{ }^{47}$ soft tissue thickness, width of the keratinized mucosa (WKM), and patient satisfaction. All of the clinical measurements were performed by one calibrated blind examiner at baseline (at the time of implant loading) and at 2, 4, and 6 months after implant loading. For the clinical measurements, the UNC manual probe was used with $0.5-\mathrm{mm}$ increments.

The primary outcome variable for this study was interproximal papilla preservation 6 months after prosthetic loading. Dental papilla preservation was evaluated clinically using a PPI described by Jemt in 1997. ${ }^{46}$ The PPI designates five different levels of papilla height. Measurements were made from the reference line connecting the highest gingival curvatures of the implant crown restoration and the adjacent tooth or crown on the buccal side. An index score of 0 was assigned when no papilla was present; 1 when less than half of the papilla was present measured from the reference line to the contact point; 2 when at least half of the papilla was present but not all the way up to the contact point; 3 when the papilla filled up the entire proximal space and was in good harmony with the adjacent papillae; and 4 when the papilla was hyperplasic. MLs were measured from the reference line drawn from the free gingival margins of the adjacent teeth (Fig. 3). The tissue level apical to the reference line was recorded as positive, whereas

† Temp Bond, Kerr, Romulus, MI. 

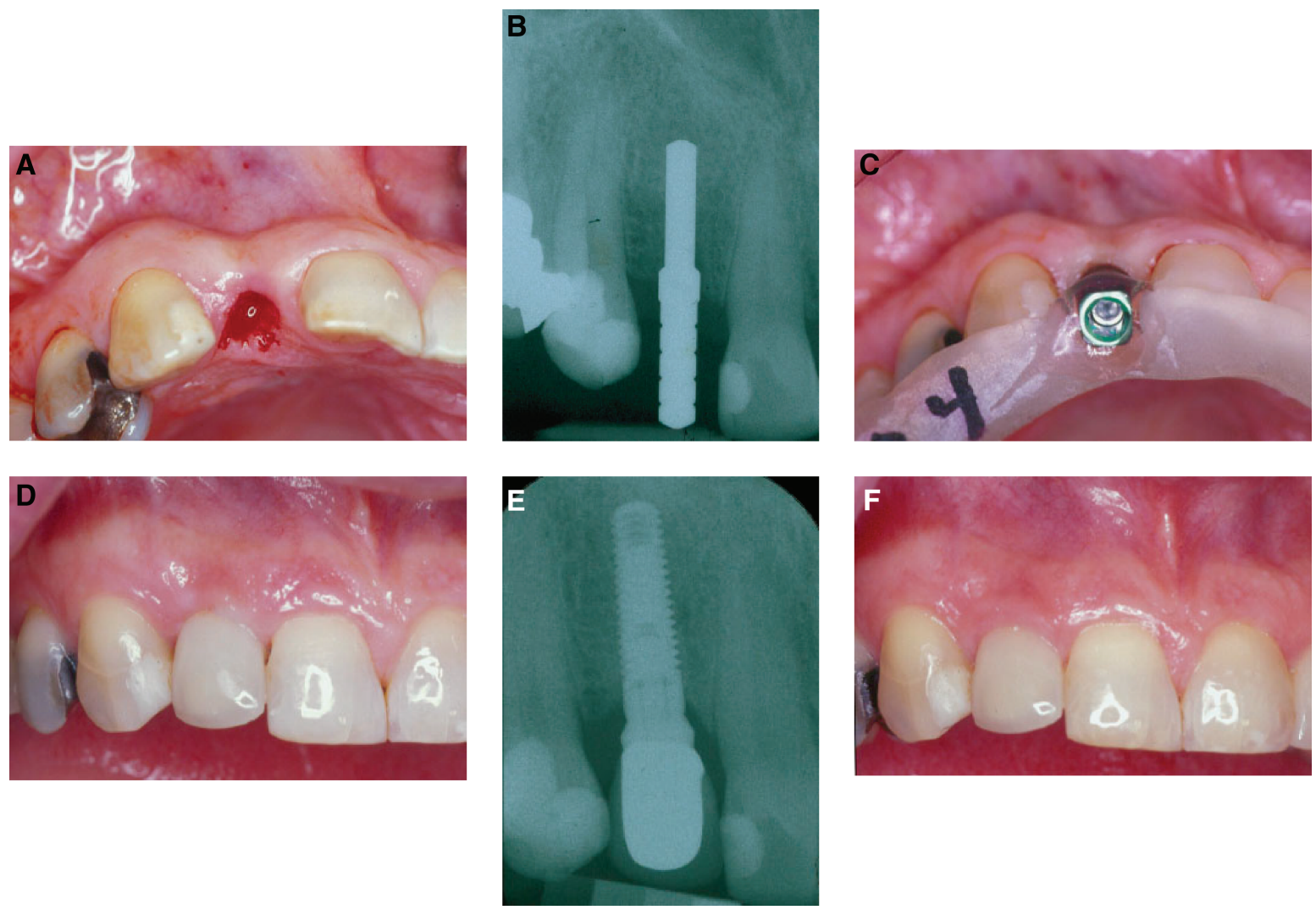

\section{Figure 2.}

Delayed loading group. A) A flapless implant surgery began with a tissue punch on the area of tooth \#7. B) The guide pin on the radiograph shows a proper angulation of implant osteotomy. C) A fixture-level transfer stent was made immediately after implant placement, with the implant mount in place. D) The permanent crown was delivered 4 months after implant placement surgery. E) The periapical radiograph demonstrates a tight connection between implant and implant restoration. F) Complete fill of the interdental papillae was observed at the 6-month visit.

a negative value was given when the tissue level was coronal to the reference. Patient satisfaction data were collected at 6 months with regard to comfort level (surgical and restorative), appearance, and function, such as chewing and speaking. For this clinical parameter, four scales were used (1, excellent; 2 , good; 3, fair; and 4, poor).

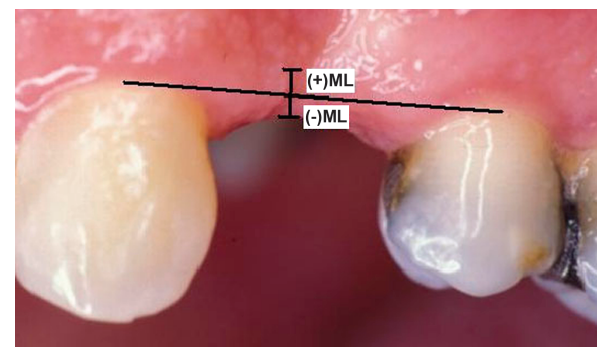

Figure 3.

Measurement of ML. A reference line, connecting the highest free gingival margins of adjacent dentition, was used to compare differences between groups and changes over time within each group.

\section{Statistical Analysis}

For non-parametric clinical parameters, such as mPI, $\mathrm{mBI}$, and PPI, the Mann-Whitney $U$ test was used to analyze differences between groups at a given time point, and the Wilcoxon signed-rank test was performed to compare a given time point with the baseline. Likewise, parametric data, such as PD, ML, and WKM, were analyzed using the Student $t$ test for comparison between the two treatment groups at a given time point and analysis of variance (ANOVA) for comparison between different time points. Data were presented as mean $\pm \mathrm{SD}$, and statistical significance was set at $\alpha=0.05$.

\section{RESULTS}

The mean age of the subjects was $45.0( \pm 15.1)$ years, ranging from 25 to 72 years, with no significant difference between the two groups (IL and DL). Fourteen women and 10 men participated in the study. Most implants (18 of 24) were placed in the maxillary premolar region, with six implants in areas of maxillary incisors. In addition, 22 of 24 were standard implants, 
sized $3.7 \times 10 \mathrm{~mm}$ or $13 \mathrm{~mm}$, with the remaining two being $4.3 \times 13 \mathrm{~mm}$. At the time of implant surgery, there was no significant difference between groups in bone quality and soft tissue thickness. Patient demographics and baseline clinical characteristics are summarized in Table 1.

Due to three failures in IL, 21 implant sites (9 IL and $12 \mathrm{DL}$ ) were evaluated. Interestingly, all three failures occurred in the first premolar region, with implant size $3.7 \times 13 \mathrm{~mm}$. The overall implant survival rate was $87.5 \%$ at 6 months, with $100 \%$ and $75 \%$ survival rates for the DL and IL groups, respectively. The results of implant survival rates and other clinical parameters evaluated are presented in Table 2.

In general, the soft tissue profile, PPI, and ML, remained stable for up to 6 months for both groups (Figs. $1 \mathrm{~F}$ and $2 \mathrm{~F}$ ). The mean PPI (the mean of mesial and distal PPI) of both groups at 6 months was 2.16 $( \pm 0.90)$. PPI in the IL group significantly increased from $1.50( \pm 0.67)$ at baseline to $2.09( \pm 0.77)$ at 2 months, and the significance remained for up to 6 months (mean PPI: $2.30 \pm 0.81 ; P<0.05$ ), whereas in the DL group, there were no significant changes found from baseline to 6 months in PPI (2.06 at both time points) (Fig. 4). There was a trend noted that PPI continuously increased from baseline (1.82 \pm $0.85)$ to 6 months $(2.16 \pm 0.90)$, but it was not statistically significant $(P>0.05)$. There were no significant differences detected between groups in PPI at each time point.

In ML, the difference at baseline between the two groups $(-0.28 \mathrm{~mm}$ for DL versus $0.17 \mathrm{~mm}$ for IL; $P$ $<0.05$ ) was no longer significant at 2 months ( 0 versus $0.08 \mathrm{~mm}$ for DL and IL, respectively) and thereafter

\section{Table I.}

\section{Demographics and Mean Baseline Clinical Characteristics (baseline: permanent crown placement)}

\begin{tabular}{|c|c|c|c|}
\hline & $\mathrm{DL}(\mathrm{N}=12)$ & $\mathrm{IL}(\mathrm{N}=12)$ & Total $(\mathrm{N}=24)$ \\
\hline Age (years)* & $47.3 \pm 17.8$ & $45.2 \pm 13.2$ & $46.3 \pm 15.4$ \\
\hline Gender & $\begin{array}{l}10 \text { females } \\
2 \text { males }\end{array}$ & $\begin{array}{l}4 \text { females } \\
8 \text { males }\end{array}$ & $\begin{array}{l}14 \text { females } \\
10 \text { males }\end{array}$ \\
\hline Tooth type & $\begin{array}{c}4 \text { incisors } \\
8 \text { premolars }\end{array}$ & $\begin{array}{c}2 \text { incisors } \\
10 \text { premolars }\end{array}$ & $\begin{array}{c}6 \text { incisors } \\
18 \text { premolars }\end{array}$ \\
\hline Bone quality* & $2.67 \pm 0.65$ & $2.92 \pm 0.29$ & $2.79 \pm 0.51$ \\
\hline Soft tissue thickness $(\mathrm{mm}) *$ & $\begin{array}{r}M: 3.17 \pm 1.01 \\
F: 2.71 \pm 0.66 \\
D: 3.25 \pm 0.75\end{array}$ & $\begin{array}{r}M: 3.00 \pm 0.97 \\
F: 2.44 \pm 0.85 \\
D: 2.72 \pm 0.91\end{array}$ & $\begin{array}{r}M: 3.08 \pm 0.90 \\
F: 2.58 \pm 0.69 \\
D: 2.99 \pm 0.79\end{array}$ \\
\hline
\end{tabular}

$M=$ mesial; $F=$ facial $; D=$ distal

* No significant differences between groups in age, bone quality, and soft tissue thickness.

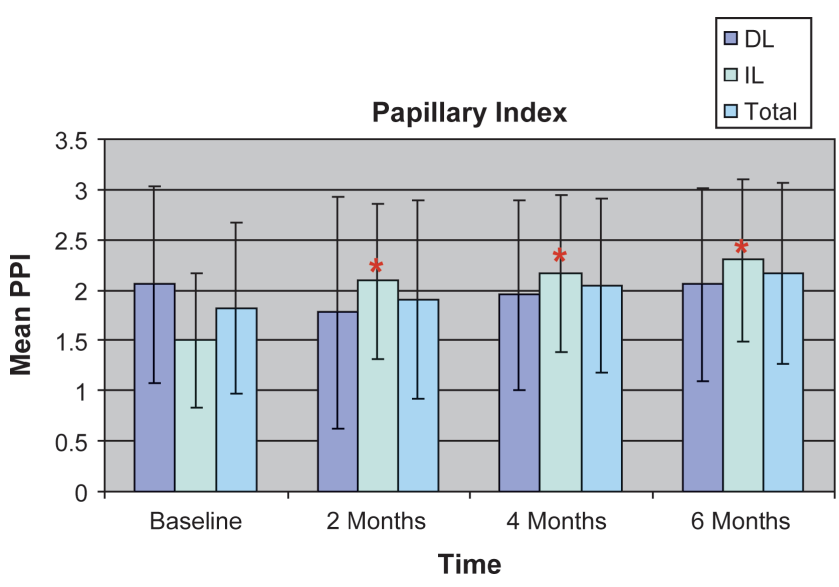

Figure 4.

Comparison of PPI between DL and IL. *Significant difference compared to baseline $(\mathrm{P}<0.05)$.

$(P>0.05)$ (Fig. 5). The mean values of ML at 6 months were $0.39( \pm 0.78) \mathrm{mm}$ and $0.17( \pm 0.39) \mathrm{mm}$ for DL and IL, respectively. No significant changes occurred in ML from baseline to 6 months in both groups.

The mean PD in each implant site was obtained from averaging PD measurements of three sites (mesio-facial, mid-facial, and disto-facial). The mean PD of DL was $2.26( \pm 0.92) \mathrm{mm}$ at baseline and 2.63 $( \pm 0.94) \mathrm{mm}$ at 6 months. Similarly, the mean values of PD in IL were $1.36( \pm 0.75) \mathrm{mm}$ and $2.08( \pm 0.73)$ $\mathrm{mm}$ at baseline and 6 months, respectively. There were no significant differences in PD between groups at each time point and over time in each group $(P>0.05)$. Moreover, there were no significant differences detected between groups at each time and over time in other clinical parameters (mBI, mPI, and WKM) $(P>0.05)$.

Patient satisfaction data, including comfort (surgical and restorative), appearance, and function, were also evaluated at 6 months. The mean values were 1.17 and 1.00 for DL and IL, respectively. All subjects in the IL group responded "excellent" to the satisfaction questionnaire, whereas 10 of 12 patients in DL answered "excellent" and the remaining two answered "good."

Analysis of the effect of baseline soft tissue thickness on PPI (data not presented in Table 2) was performed. The results demonstrated that PPI was not significantly affected by baseline soft tissue thickness $(P>0.05)$. The mean values of PPI for the thick group $(\leq 3 \mathrm{~mm})$ and the other group $(<3 \mathrm{~mm})$ were $2.29( \pm 0.86)$ and $2.14( \pm 0.90)$ at 6 months. 


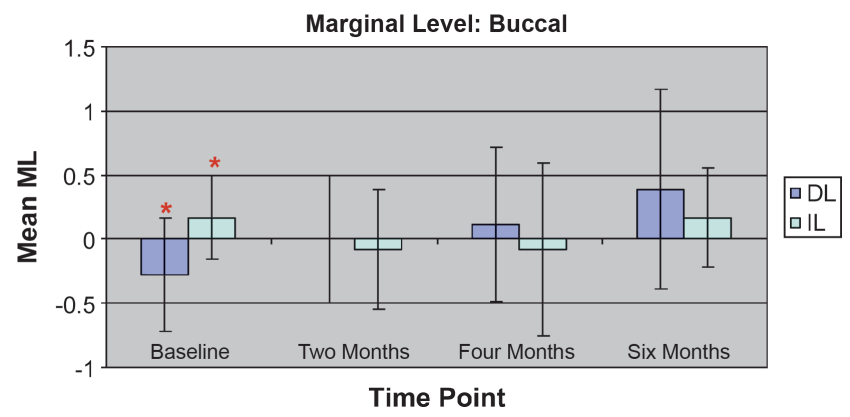

Figure 5.

Comparison of marginal soft tissue level between groups. *Significant difference between groups $(\mathrm{P}<0.05)$.

\section{DISCUSSION}

The present study was performed to investigate the effect of flapless implant surgery on soft tissue preservation in single-tooth implants, comparing immediately loaded and delayed loaded implants. All delayed loaded implants were successfully integrated and in function for 6 months, leading to a $100 \%$ success rate. However, three of 12 immediately loaded implants failed to osseointegrate, yielding a $25 \%$ failure rate. Previous studies reported a wide range of failure rates in immediately loaded singletooth implants, $0 \%$ to $19 \% .{ }^{16,40,42,43}$ A retrospective 3 -year clinical study on IL in the maxilla using flapless implant surgery reported $19 \%$ failure rate in singletooth implants, which was significantly higher than the one $(6 \%)$ in implants splinted in a partial prosthesis. ${ }^{40}$ On the other hand, other studies reported no failures in immediately loaded single-tooth implants in the anterior maxilla. ${ }^{42,43}$ The differences in the failure rate between the studies might have resulted from several factors: different case selection criteria, time of functional loading (i.e., permanent crown placement), and different surgical or prosthodontic protocols. For example, in the studies with no implant failure, permanent crowns were delivered 6 months after use of temporary crowns, ${ }^{42,43}$ whereas the permanent crown was placed in 10 to 14 days after implant placement in the present study. Moreover, some studies used flapless implant surgery whereas others raised flap to place implants. The relatively high failure rate (25\%) of the IL group in this study suggests that thorough assessment of the case (e.g., medical and dental history review, site evaluation, and surgical and prosthodontic protocol) is essential to minimize the implant failure for IL with flapless surgery.

The results of the current study showed that PPI and ML were stable for up to 6 months for both groups, without a significant difference between the two groups. An 18-month follow-up retrospective study
Table 2.

\section{Comparison of Clinical Parameters Between Groups (baseline and 2, 4, and 6 months)}

\begin{tabular}{|c|c|c|c|}
\hline & $\mathrm{DL}(\mathrm{N}=12)$ & $\mathrm{IL}(\mathrm{N}=9)$ & Total $(\mathrm{N}=2 \mathrm{I})$ \\
\hline $\begin{array}{l}\text { Survival rates } \\
\text { (\%) }\end{array}$ & 100.0 & 75.0 & 87.5 \\
\hline \multicolumn{4}{|l|}{ PPI } \\
\hline Baseline & $2.06 \pm 0.98$ & $1.50 \pm 0.67$ & $1.82 \pm 0.85$ \\
\hline 2 months & $1.78 \pm 1.15$ & $2.09 \pm 0.77 *$ & $\mid .91 \pm 0.99$ \\
\hline 4 months & $1.95 \pm 0.94$ & $2.17 \pm 0.78 *$ & $2.04 \pm 0.87$ \\
\hline 6 months & $2.06 \pm 0.96$ & $2.30 \pm 0.81 *$ & $2.16 \pm 0.90$ \\
\hline \multicolumn{4}{|l|}{$\begin{array}{l}\text { Marginal level } \\
\quad(\mathrm{mm})\end{array}$} \\
\hline Baseline & $-0.28 \pm 0.44^{\dagger}$ & $0.17 \pm 0.33^{\dagger}$ & $-0.09 \pm 0.39$ \\
\hline 2 months & $0.00 \pm 0.50$ & $-0.08 \pm 0.47$ & $-0.03 \pm 0.49$ \\
\hline 4 months & $0.11 \pm 0.60$ & $-0.08 \pm 0.67$ & $0.03 \pm 0.63$ \\
\hline 6 months & $0.39 \pm 0.78$ & $0.17 \pm 0.39$ & $0.30 \pm 0.61$ \\
\hline \multicolumn{4}{|l|}{$\mathrm{PD}(\mathrm{mm})$} \\
\hline Baseline & $2.26 \pm 0.92$ & $1.36 \pm 0.75$ & $1.87 \pm 0.85$ \\
\hline 2 months & $2.30 \pm 0.75$ & $2.05 \pm 0.7 \mid$ & $2.19 \pm 0.73$ \\
\hline 4 months & $2.22 \pm 0.87$ & $2.11 \pm 0.58$ & $2.17 \pm 0.75$ \\
\hline 6 months & $2.63 \pm 0.94$ & $2.08 \pm 0.73$ & $2.39 \pm 0.85$ \\
\hline \multicolumn{4}{|l|}{$\mathrm{mBl}$} \\
\hline Baseline & $1.22 \pm 0.67$ & $0.92 \pm 0.51$ & $1.09 \pm 0.60$ \\
\hline 2 months & $1.00 \pm 0.50$ & $0.75 \pm 0.62$ & $0.89 \pm 0.55$ \\
\hline 4 months & $1.22 \pm 0.67$ & $0.50 \pm 0.52$ & $0.91 \pm 0.61$ \\
\hline 6 months & $0.67 \pm 0.71$ & $0.50 \pm 0.52$ & $0.60 \pm 0.63$ \\
\hline \multicolumn{4}{|l|}{$\mathrm{mPI}$} \\
\hline Baseline & $0.67 \pm 0.50$ & $0.33 \pm 0.49$ & $0.52 \pm 0.50$ \\
\hline 2 months & $1.00 \pm 0.50$ & $0.58 \pm 0.51$ & $0.82 \pm 0.50$ \\
\hline 4 months & $0.78 \pm 0.44$ & $0.50 \pm 0.67$ & $0.66 \pm 0.54$ \\
\hline 6 months & $0.89 \pm 0.60$ & $0.50 \pm 0.52$ & $0.72 \pm 0.57$ \\
\hline \multicolumn{4}{|l|}{ WKM (mm) } \\
\hline Baseline & $3.67 \pm 1.73$ & $3.75 \pm 1.60$ & $3.70 \pm 1.67$ \\
\hline 2 months & $3.89 \pm 1.27$ & $4.00 \pm 1.86$ & $3.94 \pm 1.52$ \\
\hline 4 months & $3.89 \pm 1.27$ & $3.92 \pm 1.68$ & $3.90 \pm 1.45$ \\
\hline 6 months & $3.78 \pm 1.09$ & $3.83 \pm 1.40$ & $3.80 \pm 1.22$ \\
\hline $\begin{array}{l}\text { Patient } \\
\text { satisfaction } \\
\text { ( } 6 \text { months) }\end{array}$ & $1.17 \pm 0.39$ & $1.00 \pm 0.00$ & $1.10 \pm 0.22$ \\
\hline
\end{tabular}

* Significantly different from baseline (Wilcoxon signed-rank test; $P<0.05$ ). $\dagger$ Significantly different between groups (Student $t$ test; $P<0.05$ ).

assessing papilla changes over time in 25 single-tooth implants showed that the papilla height increased significantly during the observation period $(P<0.05) .{ }^{46}$ In the study, it was found that $10 \%$ of papillae were scored 3 (complete fill) in PPI at baseline, whereas 
$58 \%$ of the papillae were scored 3 in PPI at 18-month follow-up. This corresponds well with the results of PPI in the current study. However, the methodologies of the two studies were different, including retrospective versus prospective, flap versus flapless surgery, and DL versus DL and IL. Also, a longer follow-up of the current study is needed to verify the similarity between the two studies. Regarding implant esthetics on single-tooth implants, most literature has been technical or case reports, and studies on single-tooth implants with IL and/or flapless implant surgery have reported hard tissue changes and survival or success rates, not soft tissue data, such as PPI. ${ }^{16,40,42,43,48,49}$ To the authors' knowledge, the current study is the first report evaluating soft tissue profile changes (interdental papillae and soft tissue levels) on singletooth implants using flapless implant surgery and/or IL.

The interdental papilla height significantly increased during 2 months after IL. It was speculated that there was a recovery in soft tissue height around the implant crown during initial healing in the IL group and that the recovery might have resulted from tissue remodeling after surgery, including reformation of the biologic width. The increase in PPI between baseline and 2 months was not observed in DL because the baseline in DL was 4 months after implant surgery.

Knowing that patient comfort and satisfaction are critical aspects of implant therapeutics, the current study evaluated questionnaires in patient satisfaction, with scales ranging 1 to 4 (1, excellent; 2 , good; 3, fair; and 4 , poor). From the results, it was noted that the mean satisfaction scores in DL and IL at 6-month follow-up were 1.17 and 1.00 , respectively, with an overall score of 1.10. All patients of IL responded "excellent" to the questionnaire about surgical and prosthodontic comfort, appearance, and function (chewing and speech). Only two patients in DL responded "good," possibly attributable to the waiting time for loading. It was speculated that the high degree of satisfaction might have resulted from minor discomfort from the flapless implant surgery. Advantages of flapless implant surgery on patient satisfaction may include minor bleeding, less surgical trauma, decreased surgical time, and accelerated healing.

The analysis of the effect of baseline soft tissue thickness on PPI demonstrated that PPI was not significantly affected by baseline soft tissue thickness $(P>0.05)$; the mean PPI values at 6 months for the thick group $(\geq 3 \mathrm{~mm})$ and the other group $(<3 \mathrm{~mm})$ were $2.29( \pm 0.86)$ and $2.14( \pm 0.90)$, respectively, at 6 months. The results imply that factors other than baseline soft tissue thickness, such as crestal bone levels, crown shapes, and the height of contact points, could determine future papillary fill. ${ }^{50,51}$

The present study has several limitations, including small sample size, short-term follow-up, no compari- son group, and relatively high failures in the IL group. However, within the limitations of this study, it can be concluded that flapless implant surgery with soft tissue preservation may provide esthetic soft tissue results in single-tooth implants either immediately or delayed loaded. Other randomized controlled clinical trials with a large sample size and comparison group (i.e., implant surgery with flap) are recommended to verify the conclusions drawn in this preliminary study.

\section{ACKNOWLEDGMENTS}

This study was partially supported by the University of Michigan Periodontal Graduate Student Research Fund. Dental implants used in the study were donated by Zimmer Dental, Carlsbad, CA.

\section{REFERENCES}

1. Brånemark PI, Hansson BO, Adell R, et al. Osseointegrated implants in the treatment of the edentulous jaw: Experience from a 10-year period. Scand J Plast Reconstr Surg Suppl 1977;16:1-132.

2. Adell R, Lekholm U, Rockler B, Brånemark PI. A 15 year study of osseointegrated implants in the treatment of the edentulous jaw. Int J Oral Surg 1981; 10:387-416.

3. Adell R, Eriksson B, Lekholm U, Brånemark PI, Jemt T. Long-term follow-up study of osseointegrated implants in the treatment of totally edentulous jaws. Int J Oral Maxillofac Implants 1990;5:347-359.

4. Lekholm U, Gunne J, Henry P, et al. Survival of the Brånemark implant in partially edentulous jaws: A 10year prospective multicenter study. Int J Oral Maxillofac Implants 1999;14:639-645.

5. van Steenberghe D. A retrospective multicenter evaluation of the survival rate of osseointegrated fixtures supporting fixed partial prostheses in the treat ment of partial edentulism. J Prosthet Dent 1989; 61:217-223.

6. Bianco G, Di Raimondo R, Luongo G, et al. Osseointegrated implant for single-tooth replacement: A retrospective multicenter study on routine use in private practice. Clin Implant Dent Relat Res 2000; 2:152-158.

7. Palmer RM, Palmer PJ, Smith BJ. A 5-year prospective study of Astra single tooth implants. Clin Oral Implants Res 2000;11:179-182.

8. Naert I, Koutsikakis G, Duyck J, Quirynen M, Jacobs $\mathrm{R}$, van Steenberghe D. Biologic outcome of singleimplant restorations as tooth replacements: A longterm follow-up study. Clin Implant Dent Relat Res 2000;2:209-218.

9. Romeo E, Chiapasco M, Ghisofli M, Vogel G. Longterm clinical effectiveness of oral implants in the treatment of partial edentulism. Clin Oral Implants Res 2002; 13:133-143.

10. Albrektsson T, Brånemark PI, Hansson HA, Lindstrom J. Osseointegrated titanium implants: Requirements for ensuring a long-lasting, direct bone-to-implant anchorage in man. Acta Orthop Scand 1981;52:155-170.

11. Buser D, Mericske-Stern R, Bernard JP, et al. Long term evaluation of non-submerged ITI implants. Part I: 8-year life table analysis of a prospective multi-center 
study with 2359 implants. Clin Oral Implants Res 1997;8:161-172.

12. Buser D, Mericske-Stern R, Dula K, Lang NP. Clinical experience with one-stage, non-submerged dental implants. Adv Dent Res 1999;13:153-161.

13. Buser D, Weber HP, Lang NP. Tissue integration of non-submerged implants: One-year results of a prospective study with 100 ITI hollow-screw and hollowcylinder implants. Clin Oral Implants Res 1990;1:33-40.

14. Weber HP, Buser D, Fiorellini JP, Williams RC. Radiographic evaluation of crestal bone levels adjacent to nonsubmerged titanium implants. Clin Oral Implants Res 1992;3:181-188.

15. Balshi TJ, Wolfinger GJ. Immediate loading of Brånemark implants in edentulous mandibles: A preliminary report. Implant Dent 1997;6:83-88.

16. Ericsson I, Nilson H, Lindh T, Randow K. Immediate functional loading of Brånemark single tooth implants: An 18 months' clinical pilot follow-up study. Clin Oral Implants Res 2000;11:26-33.

17. Lefkove MD, Beals RP. Immediate loading of cylinder implants with overdentures in the mandibular symphysis: The titanium plasma-sprayed screw technique. J Oral Implantol 1990;16:265-271.

18. Piattelli A, Corigliano M, Scarano A, Costigliola G, Paolantonio M. Immediate loading of titanium plasmasprayed implants: An histologic analysis in monkeys. J Periodontol 1998;69:321-327.

19. Piattelli A, Paolantonio M, Corigliano M, Scarano A. Immediate loading of titanium plasma-sprayed screwshaped implants in man: A clinical and histological report of two cases. J Periodontol 1997;68:591-597.

20. Randow K, Ericsson I, Nilner K, Petersson A, Glantz PO. Immediate functional loading of Brånemark dental implants: An 18-month clinical follow-up study. Clin Oral Implants Res 1999;10:8-15.

21. Romanos GE, Toh CG, Siar CH, Swaminathan D. Histologic and histomorphometric evaluation of periimplant bone subjected to immediate loading: An experimental study with Macaca fascicularis. Int J Oral Maxillofac Implants 2002;17:44-51.

22. Testori T, Meltzer A, Del Fabbro $M$, et al. Immediate occlusal loading of Osseotite implants in the lower edentulous jaw: A munticenter prospective study. Clin Oral Implants Res 2004;15:278-284.

23. Tarnow DP, Emtiaz S, Classi A. Immediate loading of threaded implants at stage 1 surgery in edentulous arches: Ten consecutive case reports with 1 - to 5 -year data. Int J Oral Maxillofac Implants 1997;12:319-324.

24. Chiapasco M, Abati S, Romeo E, Vogel G. Implantretained mandibular overdentures with Brånemark System MKII implants: A prospective comparative study between delayed and immediate loading. Int $J$ Oral Maxillofac Implants 2001;16:537-546.

25. Chiapasco M, Gatti C, Rossi E, Haefliger W, Markwalder $\mathrm{TH}$. Implant-retained mandibular overdentures with immediate loading: A retrospective multicenter study on 226 consecutive cases. Clin Oral Implants Res 1997;8:48-57.

26. Brånemark PI, Engstrand P, Ohrnell LO, et al. Brånemark Novum: A new treatment concept for rehabilitation of the edentulous mandible. Preliminary results from a prospective clinical follow-up study. Clin Implant Dent Relat Res 1999;1:2-16.

27. Salama H, Rose LF, Salama M, Betts NJ. Immediate loading of bilaterally splinted titanium root-form implants in fixed prosthodontics - A technique reex- amined: Two case reports. Int $J$ Periodontics Restorative Dent 1995;15:344-361.

28. Schnitman PA, Wohrle PS, Rubenstein JE, DaSilva JD, Wang NH. Ten-year results for Brånemark implants immediately loaded with fixed prostheses at implant placement. Int $J$ Oral Maxillofac Implants 1997; 12:495-503.

29. Testori T, Szmukler-Moncler S, Francetti L, et al. Immediate loading of Osseotite implants: A case report and histologic analysis after 4 months of occlusal loading. Int $J$ Periodontics Restorative Dent 2001;21:451-459.

30. Stricker A, Gutwald R, Schmelzeisen R, Gellrich NG. Immediate loading of 2 interforaminal dental implants supporting an overdenture: Clinical and radiographic results after 24 months. Int J Oral Maxillofac Implants 2004; 19:868-872.

31. Lorenzoni M, Pertl C, Zhang K, Wegscheider WA. Inpatient comparison of immediately loaded and nonloaded implants within 6 months. Clin Oral Implants Res 2003a; 14:273-279.

32. van Steenberghe D, Molly L, Jacobs R, Vandekerckhove B, Quirynen M, Naert I. The immediate rehabilitation by means of a ready-made final fixed prosthesis in the edentulous mandible: A 1 -year follow-up study on 50 consecutive patients. Clin Oral Implants Res 2004; 15:360-365.

33. Choquet V, Hermans M, Adriaenssens $P$, Daelemans $P$, Tarnow DP, Malevez C. Clinical and radiographic evaluation of the papilla level adjacent to single-tooth dental implants: A retrospective study in the maxillary anterior region. J Periodontol 2001;72:1364-1371.

34. Grossberg DE. Interimplant papilla reconstruction: Assessment of soft tissue changes and results of 12 consecutive cases. J Periodontol 2001;72:958-962.

35. Van der Zee E, Oosterveld P, Van Waas MA. Effect of GBR and fixture installation on gingiva and bone levels at adjacent teeth. Clin Oral Implants Res 2004;15:62-65.

36. Auty $\mathrm{C}$, Siddiqui $\mathrm{A}$. Punch technique for preservation of interdental papillae at nonsubmerged implant placement. Implant Dent 1999;8:160-166.

37. Salinas TJ. Soft tissue punch technique for aesthetic implant dentistry. Pract Periodontics Aesthet Dent 1998; $10: 434$

38. Landsberg CJ, Bichacho N. Implant placement without flaps - Part 2: Utilizing a two-stage surgical protocol. Pract Periodontics Aesthet Dent 1999;11:169-176.

39. Campelo LD, Camara JRD. Flapless implant surgery: A 10-year clinical retrospective analysis. Int $J$ Oral Maxillofac Implants 2002;17:271-276.

40. Rocci A, Martignoni M, Gottlow J. Immediate loading in the maxilla using flapless surgery, implants placed in predetermined positions, and prefabricated provisional restorations: A retrospective 3-year clinical study. Clin Implant Dent Relat Res 2003;5(Suppl. 1):29-36.

41. Oh T-J, Shotwell J, Billy E, Byun H-Y, Wang H-L. Flapless implant surgery in the esthetic region: Advantages and precautions. Int $J$ Periodontics Restorative Dent; in press.

42. Lorenzoni M, Pertl C, Zhang K, Wimmer G, Wegscheider WA. Immediate loading of single-tooth implants in the anterior maxilla: Preliminary results after one year. Clin Oral Implants Res 2003b;14:180-187.

43. Andersen E, Haanæs HR, Knutsen BM. Immediate loading of single-tooth ITI implants in the anterior maxilla: A prospective 5-year pilot study. Clin Oral Implants Res 2002;13:281-287. 
44. Cooper L, Felton DA, Kugelberg CF, et al. A multicenter 12-month evaluation of single-tooth implants restored 3 weeks after 1-stage surgery. Int $J$ Oral Maxillofac Implants 2001;16:182-192.

45. Shotwell JL, Billy EJ, Wang H-L, Oh T-J. Implant surgical guide fabrication for partially edentulous patients. J Prosthet Dent 2005;93:294-297.

46. Jemt T. Regeneration of gingival papillae after singleimplant treatment. Int $J$ Periodontics Restorative Dent 1997; 17:327-333.

47. Mombelli A, van Oosten MA, Schurch E Jr., Land NP. The microbiota associated with successful or failing osseointegrated titanium implants. Oral Microbiol Immunol 1987;2:145-151.

48. Kan J, Rungcharassaeng K, Ojano M, Goodacre CJ. Flapless anterior implant surgery: A surgical and prosthodontic rationale. Pract Periodontics Aesthet Dent 2000;12:467-474.
49. Hahn J. Single-stage, immediate loading, and flapless surgery. J Oral Implantol 2000;26:193-198.

50. Tarnow DP, Elian N, Fletcher P, et al. Vertical distance from the crest of bone to the height of the interproximal papilla between adjacent implants. J Periodontol 2003; 74:1785-1788.

51. Tarnow DP, Magner AW, Fletcher P. The effect of the distance from the contact point to the crest of bone on the presence or absence of the interproximal dental papilla. J Periodontol 1992;63:995-996.

Correspondence: Dr. Hom-Lay Wang, Department of Periodontics/Prevention/Geriatrics, University of Michigan, School of Dentistry, 1011 N. University Ave., Ann Arbor, MI 48109-1078. Fax: 734/936-0374; e-mail: homlay@ umich.edu.

Accepted for publication November 30, 2005. 